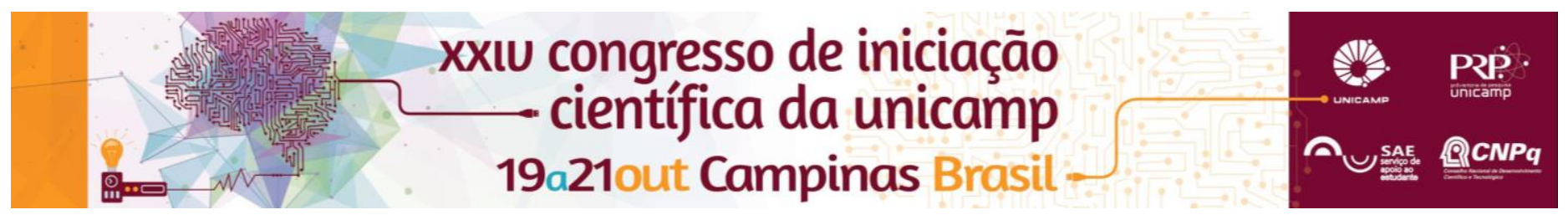

\title{
Aprimoramento de um gerador de tráfego IP
}

\section{Maria Augusta M. Moreira*, Varese Salvador Timóteo.}

\section{Resumo}

Este projeto consiste em incluir outras distribuições para os perfis de tráfego em um gerador de tráfego baseado em IP. O gerador foi desenvolvido na FT em projetos anteriores e contém apenas a distribuição exponencial. Foram implementadas e testadas as distribuições de Pareto e Normal no gerador de tráfego e validado os resultados utilizando simulações por eventos discretos.

\section{Palavras-chave:}

Modelos de Tráfego, Distribuições de Probabilidade, Protocolos .

\section{Introdução}

Os novos serviços e aplicações disponíveis na internet para a comunicação tornaram o fluxo de tráfego de rede mais detalhado e complexo, exigindo a utilização de abordagens específicas para, por exemplo, a modelagem de tráfego. O gerador de tráfego IP é composto por dois subsistemas: o gerador, que gera os pacotes de acordo com o perfil desejado para cada serviço; e o receptor, que está presente em outro elemento da rede e recebe os pacotes e armazena as informações sobre o tráfego. O gerador de tráfego contém apenas a distribuição exponencial e o objetivo do projeto foi incluir outras distribuições para simulação dos perfis de tráfego diferentes do exponencial. Para implementar as distribuições de Pareto e Normal no gerador de tráfego foi necessária a inversão das mesmas no software Mathematica. Isso porque no gerador de tráfego a função distribuição de probabilidade (PDF) é um input.

\section{Resultados e Discussão}

Foram testadas as equações inversas das distribuições Pareto e Normal no software Mathematica e ambas foram integradas no código do gerador de tráfego IP em linguagem $\mathrm{C}_{++}$. No processo de definição dos parâmetros para as variáveis das distribuições, não foi verificado o parâmetro que validasse a Normal nos testes. Após obtido os resultados dos testes compilados do programa para as equações com intervalo e duração próprios e misturados das distribuições Pareto e Exponencial, tais foram lidos e analisados no software Mathematica e plotados em CDF.

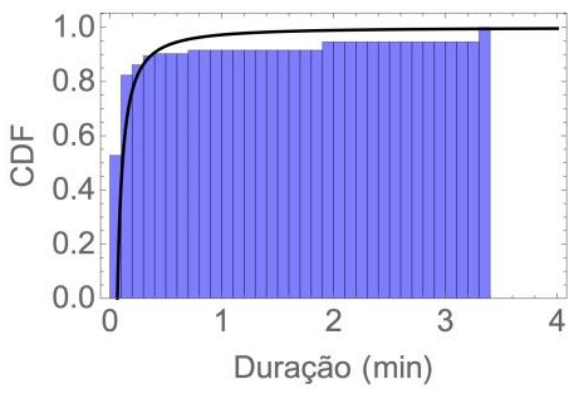

Figura 1. Gráfico com intervalo e duração próprio da Distribuição Pareto.

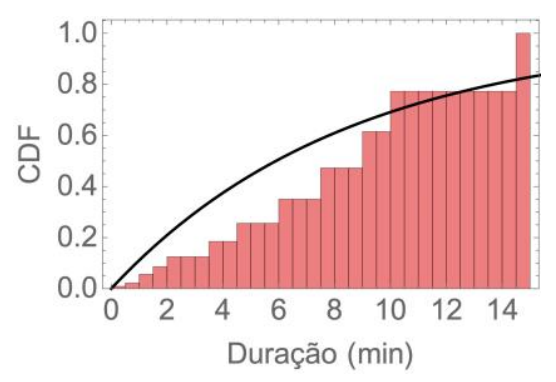

Figura 2. Gráfico com intervalo e duração próprio da Distribuição Exponencial.

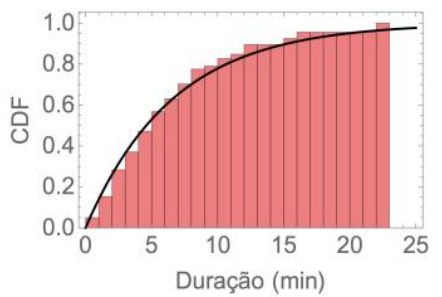

(a)

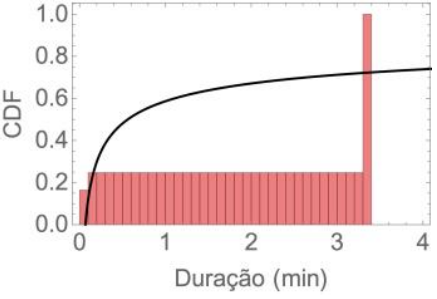

(b)
Figura 3. Gráfico com intervalo Pareto e duração Exponencial (a) e intervalo Exponencial e duração Pareto (b).

\section{Conclusões}

Como resultado das análises realizadas no projeto foi possível verificar a validação da implementação de demais distribuições diferentes da Exponencial para simulação dos perfis de tráfego IP. Adicionalmente, ambas as curvas obtidas dos resultados da mistura das distribuições apresentaram comportamentos semelhantes o reforça a validação dos resultados do projeto.

\section{Agradecimentos}

Professor Dr. Varese Salvador Timóteo; Universidade Estadual de Campinas; PIBITI

Wang, W. Zhang, X.; Shi, W.; Lian, S.; Feng, D. Understanding and Analyzing Network Traffic. Network, IEEE. IEEE Journals \& Magazines, 2012. 